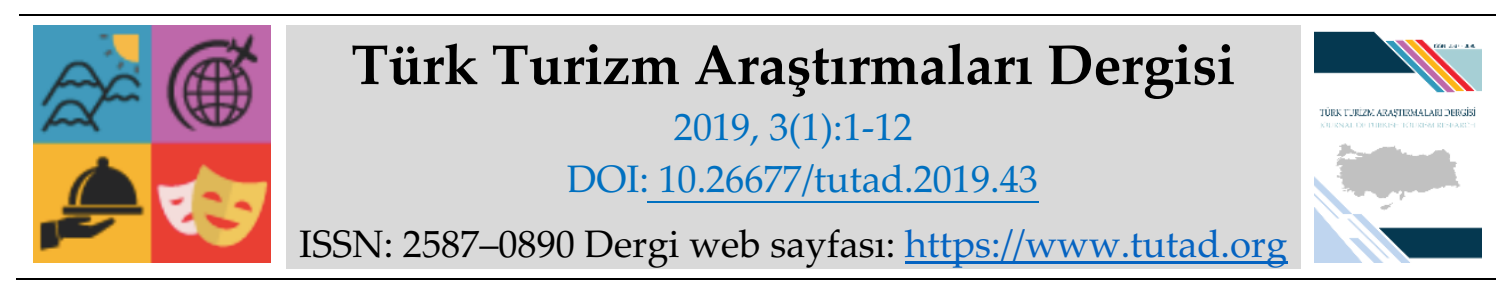

ARAȘTIRMA MAKALESI

\title{
Turizm Meslek Lisesi Öğrencilerinin Demografik Değişkenlerine Göre Mesleki Bağlılık Düzeylerinin İncelenmesi
}

Öğr. Gör. Sercan YILDIZ, İstanbul Gelişim Üniversitesi, Meslek Yüksekokulu, e-posta: seyildiz@gelisim.edu.tr

ORCID: https://orcid.org/0000-0001-5246-6855

Öğr. Gör. Levent Selman GÖKTAŞ, Harran Üniversitesi, Sosyal Bilimler Meslek Yüksekokulu, eposta: leventselmangoktas@harran.edu.tr ORCID: https://orcid.org/0000-0001-6675-3759

Tuncay HABİL, İstanbul Üniversitesi Turizm İşletmeciliği A.B.D Doktora Öğrencisi, e-posta: tuncayhabil@hotmail.com

ORCID: https://orcid.org/0000-0002-1310-8673

Prof. Dr. F. Füsun İSTANBULLU DINÇER, İstanbul Üniversitesi, e-posta: istanbul@istanbul.edu.tr

ORCID: https://orcid.org/0000-0003-2338-2462

Öz

Bu araştırma, İstanbul'da bir Mesleki ve Teknik Anadolu Lisesinde turizm eğitimi gören ve en az bir dönem turizm sektöründe staj yapmış 11. ve 12. Sınıf öğrencilerinin demografik özelliklerine göre turizme yönelik mesleki bağlılık düzeylerini belirlemek amacıyla yapılmıştır. Öğrencilerin mesleki bağlılık düzeylerinin belirlenmesinde, Meyer ve diğerleri (1993) tarafından ortaya atılan ve Tak ve Çiftçioğlu (2009) tarafından Türkçe'ye çevrilerek güvenilirlik ve geçerlilik çalışması yapılan, "Mesleki Bağlılık Ölçeği" kullanılmıştır. Veriler, okul idaresi tarafından 2016-2017 eğitim-öğretim yılında 11. ve 12. sınıfta öğrenim gören 290 öğrenciden anket tekniği ile toplanmıştır. Man Whitney-U testi ile gerçekleştirilen hipotez testleri sonucunda, öğrencilerin cinsiyet ve en son staj yaptıkları işletme özelliklerine göre, turizm mesleğine yönelik bağlılık düzeylerinde anlamlı farklılıklar tespit edilmiştir. Ayrıca araştırma sonuçları, öğrencilerin sınıf düzeylerine göre mesleki bağlılık düzeylerinde anlamlı bir farklılık olmadığını göstermektedir.

Anahtar Kelimeler: Turizm, Bağlılık, Mesleki Bağlılık, Turizm Meslek Lisesi, Staj Programı.

Makale Gönderme Tarihi: 13.09.2018

Makale Kabul Tarihi: 31.12.2018

Önerilen Atıf:

Yıldız, S., Göktaş,. L. S., Habil, T. ve İstanbullu Dinçer, F. (2019). Turizm Meslek Lisesi Öğrencilerinin Demografik Değişkenlerine Göre Mesleki Bağlllık Düzeylerinin İncelenmesi, Türk Turizm Araştırmaları Dergisi, 3(1):1-12.

(C) 2019 Türk Turizm Araştırmaları Dergisi. 


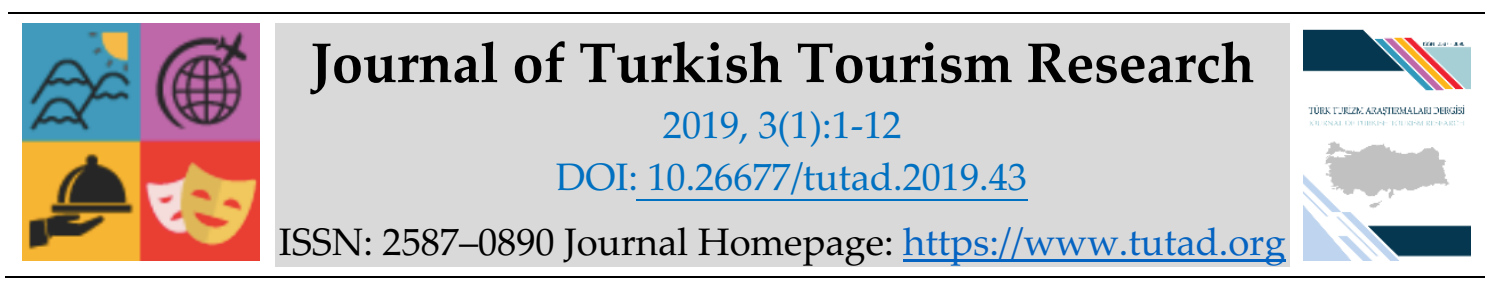

\title{
RESEARCH PAPER
}

\section{Investigation of Professional Commitment Level According to The Demographic Variables of Vocational and Technical Anatolian High School Students}

Öğr. Gör. Sercan YILDIZ, İstanbul Gelişim University, Vocational School, e-mail: seyildiz@gelisim.edu.tr ORCID: https://orcid.org/0000-0001-5246-6855

Öğr. Gör. Levent Selman GÖKTAŞ, Harran University, Vocational School of Social Sciences, e-mail: leventselmangoktas@harran.edu.tr ORCID: https://orcid.org/0000-0001-6675-3759

Tuncay HABİL, İstanbul University Tourism Management, Ph.D Student, e-mail: tuncayhabil@hotmail.com ORCID: https://orcid.org/0000-0002-1310-8673

Prof. Dr. F. Füsun İSTANBULLU DİNÇER, İstanbul University, İstanbul, e-mail: istanbul@istanbul.edu.tr ORCID: https://orcid.org/0000-0003-2338-2462

\begin{abstract}
This research was conducted so as to determine the level of professional commitment towards tourism according to some demographic characteristics of 11th and 12th grade students who have been trained tourism in a Vocational and technical Anatolian High School in Istanbul and who have completed at least one term internship in tourism sector. In determining the level of professional commitment of students, "Professional Commitment Scale" by put forward Meyer et al. and Tak and Çiftçioğlu translated it into Turkish and conducted a reliability and validity study is used. Data were collected with questionnaire technique by the school administration from 290 students in 11th and 12th grade studying in the 2016-2017 academic year. As a result of the hypothesis tests performed by the Man Whitney-U test, significant differences were found in the level of commitment towards tourism profession, according to the students' gender and the characteristics of the business to do their internship. Also the results of the research show that there is no significant difference in the level of professional commitment according to the class levels of the students.
\end{abstract}

Keywords: Tourism, Commitment, Professional Commitment, Vocational and Technical Anatolian High School, İnternship Program.

Received: 13.09.2018

Accepted: 31.12 .2018

\section{Suggested Citation:}

Yıldız, S., Göktaş,. L. S., Habil, T. and İstanbullu Dinçer, F. (2019). Investigation of Professional Commitment Level According to The Demographic Variables of Vocational and Technical Anatolian High School Students, Journal of Turkish Tourism Research, 3(1):1-12.

(C) 2019 Türk Turizm Araştırmaları Dergisi. 


\section{Gíriş}

Bir turizm işletmesinin varlığını koruyup, büyüyebilmesi için müşteri memnuniyet düzeyinin yüksek olması gerekmektedir. Emek yoğun bir sektör olmasından dolayı, turizm işletmelerinde müşteri memnuniyeti sağlanmasında en önemli faktörlerden bir tanesi de iş görenlerin sunduğu kaliteli hizmettir. Bu sebeple, turizm sektöründe faaliyet gösteren işletmeler, diğer sektörlerden farklı olarak iş gören konusunda daha dikkatli olmalıdır. Bu noktada, turizm işletmelerinde insan kaynakları yönetiminde çalışanların mesleki bağlılığı yüksek iş görenleri seçmesi ve işletmeye kazandırması önem arz etmektedir. Profesyonel bağlılık olarak da adlandırılan mesleki bağlılık, uzmanlık kazanma amacı taşıyan bireyin yaşamında mesleğine verdiği önem derecesini ifade etmektedir. Aslan'a göre (2008: 165) mesleki bağllık, bireyin belirli bir alanda beceri ve uzmanlık kazanmak amacıyla yaptığı çalışmalarının sonucunda mesleğini yaşamında ne derece merkezi bir konumda değerlendirdiğidir. Başka bir tanıma göre mesleki bağlılık ise, "mesleğe ve mesleki kariyere bağlılık ve mesleğe ve meslekî kariyere kişinin kendini adaması ve meslekî etik ve meslekî amaçlara inanması ve bunları kabul etmesidir" (Şimşek ve Aslan, 2012: 420). Bu tanımlamalardan hareketle mesleki bağlılık ile örgütsel bağlllık birbiri ile karıştırılmamalıdır. Mesleki bağlılık; bireyin belirli bir dalda beceri ve uzmanlık kazanmak üzere yaptığı çalışmalar sonucunda mesleğinin yaşamındaki önemi ve ne kadar merkezi bir yere sahip olduğu ile ilgilidir (Baysal ve Paksoy, 1999: 8). Ancak örgütsel bağlılıkta birey açısından en merkezi yerde örgütün kendisi bulunmaktadır. Bu noktada mesleki bağlılık, örgütsel bağlılıktan ayrılmaktadır.

Meslek liseleri, bir mesleğe yönelik pratik ve teorik bilgilerin birlikte verilerek, henüz mesleğe tam olarak atılmadan, o mesleğe ilişkin birçok bilgi ve beceriyi öğretmeyi amaçlayan, öğrencilerin ilgili mesleki becerilerini geliştirerek, işletmelerin teknik ve kalifiye eleman desteğini sağlamaya çalışan eğitim-öğretim kurumlarıdır. Bu sebeple meslek liseleri, öğrencilerin yeteneklerini ortaya çıarmaya, öğrencileri mesleğe ve dolayısıyla hayata hazırlamaya yardımcı olmaktadır. Bu çalışmada, turizm meslek lisesi öğrencilerinin turizm mesleğine ilişkin bağllık düzeyleri üzerinde etkili olan demografik değişkenlerin belirlenmesi amaçlanmaktadır. Bu değişkenlerin önceden belirlenmesi araştırmacılara, turizm meslek lisesi öğrencilerinin mesleklerine olan bağlılık ve istek düzeylerine ilişkin önemli ipuçları vererek, mesleklerinde ve hayatlarında daha başarılı bireyler olmalarına yardımcı ve/veya yönlendirici bilgiler sunacağı düşünülmektedir.

\section{MESLEKİ BAĞLILIK KAVRAMI VE DÜZEYLERİNIN ÖLÇÜLMESİ}

Mesleki bağlllık, genel olarak, bireyin mesleğinin yaşamında ne kadar merkezi bir yere sahip olduğuna ve mesleğine ilişkin tutum ve algılarını ifade etmektedir (Çetin, vd., 2016: 291 ve Çelik ve Yıldız, 2018: 49). Vandenberg ve Scarpello (1994), bireyin duygusunu davranış eğilimi odaklı yorumlayarak mesleki bağlılığın, insanlar ile meslekleri arasında ve kişinin iş değerine olan inancı ve bunu benimsemesi ile meslek seçimi arasında bulunan psikolojik bir bağlılık olarak ifade etmektedir (Akt: Lin vd., 2014: 68).

Mesleki bağlılığın önemi, bireylerin tutum ve davranışları açısından her geçen gün artmaktadır. Bunun en büyük nedeni de istihdam güvenliğinin azaldığı bir çağda mesleki bağlılığın önemli bir tanımlama ve süreklilik kaynağı olduğu düşünülmektedir (Van der Heijden vd., 2009: 617). Bu çerçevede ilgili literatürde mesleki bağlllık kavramının nasıl ölçülebileceğine ilişkin çalışmalar son yıllarda ağırlık kazanmaktadır. Ayrıca, örgütsel bağlılık çerçevesinde izlenen gelişime paralel olarak mesleki bağlllık çalışmalarının da ilgili literatürü zenginleştirmeye başladığı gözlemlenmektedir (Tak ve Çiftçioğlu, 2008: 157). Ancak, mesleki bağllılk konusunda ki çalışmaların yetersizliğine dikkat çeken Meyer vd. (1993), bireyin mesleğine olan bağlılığını çok boyutlu olarak ele almış ve bireylerin mesleklerine karşı duygusal, 
devamlılık ve normatif olarak bağlı olduklarını öne sürmüştür (Blau, 2003: 469-470). Bu noktadan hareketle, duygusal bağlllık; örgüt amaç ve değerlerini benimseyerek içinde bulunduğu işletmede veya kurumda kariyerini sürdürme konusunda istekli olmak ve örgüt çıkarları için çaba sarf etmeye gönüllü olmak olarak tanımlanmaktadır (Çekmecelioğlu, 2006: 296). Devamlılık bağlılığı ise; örgütten ayrılmanın getireceği yüksek maliyetleri göze alamamayı, mesleğe vazgeçemeyecek kadar çok yatırım yapmış olmayı ve harcanan zaman ve emek sonucunda kazanılan para ve statünün meslekten ayrılma sonucunda kaybedilmesi ile sonuçlanacağ düşüncesiyle oluşan bağlılıktır (Özmen vd., 2005: 3; Başol ve Yalçın, 2009: 4-5). Son olarak normatif bağlılık ise; temelinde zorunluluk hissiyatını barındırmakla birlikte, örgüte karşı kişinin kendisini yükümlü hissetmesi ile meydana gelmektedir. İş görenlere sağlanan yardımlar (nakit avans, eğitim, ödüllendirme vb.) karşısında iş görenlerin kendilerini örgüte karşı borçlu hissetme inancına sahip olmaları ve bu inanç sonucunda iş görenlerin sağlanan yardımların karşılığını ödeme zorunluluğu hissetmesi bu bağlılık türü içerisinde ortaya çıkmaktadır (Çolakoğlu vd., 2009: 79).

Literatürde yapılan çalışmalar, sıklıkla mesleki bağlılık ve örgütsel bağlılık arasındaki ilişkiye odaklanmıştır. Örneğin Uysal, 2013 yılında 317 stajyer katılımcı/çalışan ile yapmış olduğu "mesleki bağlllık gelişimine örgüt ikliminin etkisi" konulu çalışmasında, olumlu örgüt ikliminin pozitif mesleki bağlılık ortamı yarattığını saptamıştır. Negatif bir örgüt ikliminin ise mesleğin ilk uygulamasıyla tanışan stajyerleri yanlış bir mesleki bağlılık gelişimine yönelttiği veya meslekten soğuttuğu ortaya çıkmıştır (Uysal, 2013). Güneş vd., 2009 yılında 329 katılımcı/çalışan dâhil ederek yapmış oldukları çalışma sonucunda, katılımcıların örgütlerine ilişkin duygusal bağlılıklarının yüksek olduğunu ve bu durumun, Türkiye'de yaşayan insanların ülkesine ve işine/mesleğine sadık bireyler olarak yetişmesinden kaynaklandığını ifade etmişlerdir. Yine aynı çalışmada, kadın çalışanların erkek çalışanlara göre mesleki bağlılık düzeylerinin daha düşük olduğu ortaya çıkmıştır. Bu durumun kaynağı olarak kadınların hem iş hem de ev hayatında ki sorumluluklarının erkeklere göre daha fazla olmasından kaynaklandığı belirtilmiştir (Güneş vd., 2009).

Bazı araştırmacılar bireylerin çalıştıkları örgüt yerine mesleklerine bağlanma eğilimlerinin arttığı görüşündedirler. Buna göre örgütlerin yapılanma biçimi ve çalışma koşullarında meydana gelen değişimler çalışanların kariyer gelişimlerini belirsizleştirmekte ve bireyler çalıştıkları örgüte karşı olumsuz bir tutum geliştirmektedirler (Morrow, 1993: 33). Bazı çalışmalara göre ise (Carson vd., 1995: 303; Carson ve Carson, 1997: 65- 67; Blau, 2003: 471-472) bireyler, çevresel ve örgütsel belirsizlikle baş edebilmek için üzerinde kontrol güçlerinin daha fazla olduğu mesleklerine yatırım yapmakta; yani, örgütlerine bağlanmaktansa mesleklerine bağlanmayı tercih etmektedirler.

Bazı durumlarda mesleki bağlllı̆̆ı yüksek olan bireylerin, örgüte bağl1lığı aynı düzeyde yüksek olmayabilir. Bu durumda çalışanlar, örgüte bağlılık düzeyleri düşük olmasına rağmen mesleki bağlılıklarını devam ettirerek, işletmeden ayrılmamaktadır. Carson vd., 1996 yılında yapmış oldukları çalışma sonucunda, mesleki bağlılık düzeyi yüksek olan, fakat örgütsel bağlılık düzeyi düşük olan bireylerin, meslekten ayrılma maliyetlerinin yüksek olmasından veya iş alternatiflerinin eksikliğinden dolayı örgüt üyeliğini devam ettirdiklerini saptamıştır (Carson vd., 1996). Ancak bu durum, İlerleyen zamanlarda örgüt içerisinde giderek mutsuzlaşan bireylerin mesleki bağlılık düzeylerinin de düşmesine, birey açısından telafisi mümkün olmayan (iş/meslek değişikliği vb.) sonuçların ortaya çıkmasına sebep olabilmektedir. Bu noktada, bireylerin mesleki bağlılık düzeylerinin, ileride çalışacakları sektöre uygun olup olmadığının belirlenmesinin önemi açığa çıkmaktadır. 


\section{METODOLOJi}

Bu araştırma, İstanbul'da bir Turizm Meslek Lisesi'nde öğrenim gören ve en az bir dönem (5 ay) turizm sektöründe staj yapmış 11. ve 12. sınıf öğrencilerinin demografik değişkenlerine göre mesleki bağlılık düzeylerini belirlemek amacıyla yapılmıştır. Bu amaca uygun olarak çalışmada, nicel araştırma yöntemleri kullanılmıştır. Veriler Anket tekniği ile toplanmıştır. Araştırmada kullanılan anket, iki bölümden oluşmaktadır. İlk bölümde 3 adet demografik ve sosyo-ekonomik soru yer almaktadır. Bu sorular, öğrencilerin mesleki bağlılık algılarını etkileme gücü olduğu varsayılan öğrencilerin cinsiyeti, sınıf düzeyleri ve çalıştıkları turizm işletmesi sorularından oluşmaktadır. Turizm sektörünün görece yoğun bir emek sektörü olmasından mütevellit, öğrencilerin mesleklerine olan bağlllık düzeylerinde cinsiyetlerinin anlamlı etkisi araştırılmak istenmiştir. Benzer şekilde öğrencilerin sınıf düzeyleri, mesleğe ilişkin öğrenilen bilgileri seviyesini ve meslek tecrübelerini değiştirmektedir. Özellikle lise son sınıf öğrencilerinin mesleklerine karşı hala belli bir bağlılık duymaları, onların kariyer planları üzerinde etkili olacaktır. Bu çerçevede çalışmada, öğrencilerin sınıf düzeylerine göre mesleki bağlılık algılarında anlamlı farklılıklar test edilmek istenmiştir. Son olarak öğrencilerin staj dönemlerinde çalıştıkları işletmeler, onların sektördeki ilk meslek tecrübeleridir. Bu işletmelerden alınacak tecrübe, öğrencilerin üzerinde planlama aşamasında olumlu veya olumsuz önemli derecede etkili olacaktır. Bu sebeple, öğrencilerin staj yaptıkları işletmeye göre öğrencilerin mesleki bağlılık algılarındaki anlamlı farklılıklar test edilmek istenmiştir.

İkinci bölümde ise, öğrencilerin mesleki bağlılık düzeylerinin belirlenmesi amacıyla 18 adet soruya yer verilmiştir. Bu bölümde kullanılan anket sorularını Meyer vd., (1993) tarafından ortaya atılan ve Tak ve Çiftçioğlu (2009) tarafından Türkçe'ye çevrilerek güvenilirlik ve geçerlilik çalışması yapılan Mesleki Bağlılık Ölçeği oluşturmaktadır (Meyer vd., 1993 ve Tak ve Çiftçioğlu, 2009). Tüm ölçüm araçlarında "1- Kesinlikle katılmıyorum" ve "7-Kesinlikle Katılıyorum" şeklinde dizayn edilmiş yedi maddeli Likert tipi ölçek kullanılmıştır. Araştırmaya katılacak öğrenciler, en az bir dönem turizm sektöründe staj deneyimine sahip olan 11. ve 12. sinıf öğrencilerinden, tabakalı örnekleme yöntemi kullanılarak belirlenmiştir. Her tabakadan (Sınıf) bağımsız olarak, rasgele örnekleme ile örneklem seçilmiştir. Buradaki temel amaç, mesleki bağlllıkları incelenen farklı sınıf ve departmanda staj yapan öğrencilerin araştırmaya dahil edilmesidir. 2016-2017 eğitim-öğretim döneminde, İstanbul'da bir Turizm Meslek Lisesi'nde öğrenim gören 11. ve 12. Sınıf öğrencilerinin sayısı 410'dur. Bu çalışma kapsamında 290 anket verisi toplanmıştır. Bu rakam, örnekleme ilişkin kabul edilebilir hata değeri \pm 0.5 olarak alındığında, evrenin \%99'undan fazlasını temsil etme gücüne sahiptir (Yazıcıoğlu ve Erdoğan, 2004: 50).

Meslek Liselerinde uygulanan staj programları, öğrencilerin mesleklerine ilişkin teorik bilgilerin yanında, pratik bilgilerin de öğrenilmesi açısından önemlidir. Ayrıca staj programları, öğrencilerin mesleki hedeflerini belirlemede, kariyerlerini planlamada ve en nihayetinde, öğrencilerin mesleklerine ilişkin mesleki bağlllık düzeylerinin belirlenmesinde önemli bilgiler sunan faydalı bir dönemdir. Buradan hareketle, mesleklerinin henüz başında bulunan turizm meslek lisesi öğrencilerinin mesleki bağlllık düzeylerinin bilinmesi ve bu doğrultuda gereken eğitim ve bilginin öğrencilere kazandırılması, ülkemiz turizm sektörünün içinde bulunduğu mesleki sıkıntılar göz önüne alındığında, başta mesleğine bağlı kalifiye eleman ihtiyacı olmak üzere, sektöre ilişkin bir çok sorunun çözümüne yardımcı olabilecektir. Bu noktada, öğrencilerin demografik özelliklerinin ortaya çıkan bu mesleki bağlılık düzeyinde ne derece etkili olduğunun veya olmadığının bilinmesi de önemli olabilir. Bu sebeple, ilgili literatür doğrultusunda aşağıda verilen araştırma hipotezleri sınanmıştır: 
H1: Öğrencilerin cinsiyetlerine göre turizm mesleğine yönelik bağlllık düzeylerinde anlamlı farklllık vardir.

H2: Öğrencilerin sinıf düzeyine göre turizm mesleğine yönelik bağlllık düzeylerinde anlamlı farklılık vardir.

H3: Öğrencilerin en son çalıştıkları turizm işletmesine göre turizm mesleğine yönelik bağlllık düzeylerinde anlaml farklllık vardır.

\section{ÖLÇEĞE İLIŞKIN GÜVENILİRLIK VE GEÇERLILIIK ANALİZLERİ}

Literatürde ölçek güvenilirliğiyle ilgili en yaygın kullanılan kıstas, Cronbach's Alpha iç tutarlılık değeridir. Yapılan güvenilirlik analizi sonucunda, bu çalışmada kullanılan mesleki bağlılık ölçeğinin Cronbach's Alpha iç tutarlılık değeri 0,920 olarak bulunmuştur. Bulunan bu değer, bir bütün olarak ölçeğin son derece güvenilir olduğunu göstermektedir (Hair vd., 2006: 118). Ölçek geçerliliğinin test edilmesi amacıyla ise "Açıklayıcı Faktör Analizi (AFA)" yönteminden yararlanılmıştır. Bir ölçeğe ait geçerliliğin faktör analizi yöntemi ile belirlenmesi için, o ölçüme ait veri setinin faktör analizi yöntemine uygun olması gerekmektedir. Verilerin açıklayıcı faktör analizine uygunluğu, Kaiser-Meyer-Olkin (KMO) Katsayısı ve Barlett Küresellik Testi ile incelenebilir. Faktörleşebilirlik için KMO katsayısının 0,6' dan büyük olması ve Barlett Küresellik Testi analizi kapsamında hesaplanan ki-kare istatistiğinin ise anlamlı çıkması beklenmektedir (Büyüköztürk, 2011: 126). Yapılan analizler sonucunda bu çalışmada kullanılan ölçeklere ilişkin KMO katsayısı 0,901 olarak ölçülmüş, Bartlett Küresellik Testi anlamlılık değeri ise $p<, 000$ düzeyinde anlamlı bulunmuştur. Bulunan her iki değer, çalışmada kullanılan ölçeğin ve veri setinin faktör analizi için uygun olduğunu göstermektedir.

Faktör analizinde, faktörler altında kümeleşen her bir ifadeye ait faktör yük değerinin 0,40 ya da daha yüksek olması, seçim için iyi bir ölçüdür (Büyüköztürk, 2011: 126). Dolayısıyla bu çalışma kapsamında yapılan açıklayıcı faktör analizinde faktör yükü alt sınırı 0,40 olarak seçilmiştir. Ardından 18 ifade, Direkt Oblimin döndürme yöntemi ile açıklayıcı faktör analizine tabi tutulmuştur. Birden fazla faktör altında toplanan (binişik) bir ifade (ifade 18) ve faktör yükü 0,40'ın altında olan bir ifade (ifade 11) analizden çıkartılmıştır. Geriye kalan 16 ifade, tekrar Direkt Oblimin döndürme yöntemi ile açıklayıcı faktör analizine tabi tutulmuş ve öz değeri birden büyük üç faktör elde edilmiştir. Elde edilen üç faktörün toplam varyans açılama oranı $\% 65,504$ olup, kabul edilebilir düzeydedir (Nakip, 2003: 412). Açılayıcı faktör analizi sonuçları Tablo.1'de gösterilmiştir.

Tablo.1'de verilen Açıklayıcı Faktör Analizi sonuçları incelendiğinde, elde edilen faktör yapısı, ölçeğin ortaya atıldığı çalışmanın bulguları ile benzerlik göstermektedir (Meyer vd., 1993: 544). Analiz sonucunda elde edilen birinci faktör, toplam varyansın $\% 43,827$ 'sini açılamaktadır. İkinci faktör, toplam varyansın $\% 15,487$ 'sini açıklamaktadır. Üçüncü ve son faktör ise toplam varyansın \%6,191'ini açıklamaktadır. Ölçeği oluşturan faktörlerin, kapsadıkları ifadeler göz önüne alındığında, orijinal ölçeğe sadık kalınarak "Normatif Bağhllık", "Duygusal Bağllık" ve "Devamlılık Bağgllı̆̆ı" olarak adlandırılması uygun görülmüştür.

Çalışma kapsamında ayrıca, mesleki bağlılık ölçeğini oluşturan her bir faktörün Cronbach's Alpha iç tutarlılık değeri de analiz edilmiştir. Tablo.1'de gösterildiği üzere, "Devamlılık Bağhllı̆̆ı" faktörünün Cronbach's Alpha iç tutarlılık değeri 0,509 ile kabul edilebilir değerin $(\alpha>0,5)$ çok az üstünde bulunmuştur (Chakrapani, 2004: 100). Bu faktöre ait Cronbach's Alpha iç tutarlılık değerinin bu denli düşük çıkmasının nedeni, ilgili faktör altında kümeleşen ifade sayısının az olmasıdır (Cortina, 1993: 100). Analiz sonucunda, "Normatif Bağhllık" ve "Duygusal Bağlllık" faktörlerinin Cronbach's Alpha iç tutarlılık değerleri ise 0,894 ve 0,909 olarak yüksek derecede 
güvenilir bulunmuştur (Cronbach, 1990). Bulunan bu değerler, faktörleri oluşturan ifadelerin bir bütün oluşturarak, ölçümün güvenilir olduğunu göstermektedir (Büyüköztürk, 2011: 126).

Tablo.1 Açıklayıcı Faktör Analizi Sonuçları

\begin{tabular}{|c|c|c|c|}
\hline Boyutlar & Ölçek Iffadeleri & Faktör Yükü & Varyans Oranı \\
\hline \multirow{8}{*}{$\begin{array}{l}\text { Normatif Băğllık } \\
\alpha=0,894\end{array}$} & İfade 17 &, 847 & \multirow[t]{8}{*}{$\% 43,827$} \\
\hline & Ifade 16 &, 836 & \\
\hline & Ífade 10 & 829 & \\
\hline & İfade 9 & ,726 & \\
\hline & İfade 15 & 646, & \\
\hline & İfade 8 & ,603 & \\
\hline & Ífade 14 &, 566 & \\
\hline & Ífade 7 &, 542 & \\
\hline \multirow{6}{*}{$\begin{array}{l}\text { Duygusal Bağlılık } \\
\alpha=0,909\end{array}$} & Ifade 4 &,- 942 & \multirow[t]{6}{*}{$\% 15,487$} \\
\hline & Ifade 3 &,- 923 & \\
\hline & Ifade 5 &,- 889 & \\
\hline & Ifade 2 &,- 842 & \\
\hline & Ifade 6 &,- 792 & \\
\hline & Ifade 1 &,- 577 & \\
\hline \multirow{2}{*}{$\begin{array}{l}\text { Devamlılık Băğlılı̆̆ } \mathbf{~} \\
\alpha=0,509\end{array}$} & İfade 13 & 871 & \multirow[t]{2}{*}{$\% 6,191$} \\
\hline & Ifade 12 &, 606 & \\
\hline \multicolumn{2}{|c|}{$\begin{array}{l}\text { Toplam Varyans Açıklama Oranı: \%65,504 } \\
\text { KMO.0 } 901\end{array}$} & \multicolumn{2}{|c|}{$\alpha=$ Cronbach's Alpha İçsel Tutarllık Dę̆ } \\
\hline
\end{tabular}

\section{ARAŞTIRMA BULGULARI}

Araştırmaya katılan öğrencilerin demografik özellikleri Tablo.2'de gösterilmiştir. Tablo.2'ye göre, ankete katılan öğrencilerin \%51,4'ü erkektir. Sınıf olarak araştırmaya katılan öğrenciler incelendiğinde \%50,3'ünun 11. sınıf öğrencisi olduğu görülmektedir. Son olarak öğrencilerin en son staj yaptıkları işletmeler incelendiğinde \%73,1'inin Konaklama/Otel sektöründe staj yaptıkları görülmektedir.

Tablo.2 Öğrencilerin Demografik Özelliklerine Göre Betimsel İstatistikler

\begin{tabular}{lll}
\hline Cinsiyet & $\boldsymbol{N}$ & $\boldsymbol{\%}$ \\
\hline Kadın & 141 & 48,6 \\
Erkek & 149 & 51,4 \\
Toplam & 290 & 100 \\
\hline Sinif & $\boldsymbol{N}$ & $\boldsymbol{\%}$ \\
\hline 11. Sinf & 146 & 50,3 \\
12. Sinif & 144 & 49,7 \\
Toplam & 290 & 100 \\
\hline İsletme & $\boldsymbol{N}$ & $\mathbf{\%}$ \\
\hline Konaklama/Otel & 212 & 73,1 \\
Seyahat/Acente & 78 & 26,9 \\
Toplam & 290 & 100 \\
\hline
\end{tabular}


Araştırma kapsamında turizm lisesi öğrencilerinin cinsiyetlerine göre mesleki bağllık algılarındaki anlamlı farklılıkları belirlemek için verilen $\mathrm{H} 1$ araştırma hipotezinin testi için öncelikle veri setinin parametrik testler için uygunluğu kontrol edilmiş ve ilk olarak normallik varsayımı araştııılmıştır. Ancak, yapılan analizler sonucunda veri setinin, $\mathrm{H} 1$ araştırma hipotezi için verilen her bir bağımsız değişken grubunda normal dağılıma sahip olmadığı, başka bir ifadeyle parametrik testlerin kullanılması için gerekli varsayımın sağlanamadığı görülmüştür. Bu sebeple, verilen araştırma hipotezinin testi için, bağımsız iki değişken grubu arasındaki anlamlı farklılıkları ortaya çıkaran ve non-parametrik bir test olan Man Whitney-U testinin kullanılmasına karar verilmiştir. Yapılan Man Whitney-U testi sonuçları Tablo.3'de gösterilmiştir.

Tablo.3 Öğrencilerin Mesleki Bağlılık Düzeylerinin Cinsiyete Göre Karşılaştırılması

\begin{tabular}{|c|c|c|c|c|c|c|c|c|c|}
\hline \multirow[t]{2}{*}{ Faktörler } & \multicolumn{4}{|c|}{ Kadın } & \multicolumn{2}{|c|}{ Erkek } & $u$ & $Z$ & $P$ \\
\hline & $N$ & $\begin{array}{l}\text { Sira } \\
\text { Ort. }\end{array}$ & $\begin{array}{l}\text { Sira } \\
\text { Top. }\end{array}$ & $N$ & $\begin{array}{l}\text { Sira } \\
\text { Ort. }\end{array}$ & $\begin{array}{l}\text { Sira } \\
\text { Top. }\end{array}$ & & & \\
\hline $\begin{array}{l}\text { Normatif } \\
\text { Bă̆lılık }\end{array}$ & 137 & 119,56 & 16379,50 & 140 & 158,03 & 22123,50 & $\begin{array}{c}6926,50 \\
0\end{array}$ & $\begin{array}{c}- \\
4,003\end{array}$ &, $000^{* *}$ \\
\hline $\begin{array}{l}\text { Devamlılık } \\
\text { Bağgllı̆̆ı }\end{array}$ & 140 & 134,01 & 18761,00 & 147 & 153,52 & 22567,00 & $\begin{array}{c}8891,00 \\
0\end{array}$ & $\begin{array}{c}- \\
2,013\end{array}$ &, $044^{*}$ \\
\hline $\begin{array}{l}\text { Duygusal } \\
\text { Bağglılık }\end{array}$ & 134 & 133,19 & 17847,50 & 145 & 146,29 & 21212,50 & $\begin{array}{c}8802,50 \\
0 \\
\end{array}$ & $\begin{array}{c}- \\
1,367\end{array}$ & ,173 \\
\hline
\end{tabular}

${ }^{*} p<0,05{ }^{* *} p<0,01$

Tablo.3'de verilen Man Whitney-U testi sonuçları incelendiğinde, öğrencilerin cinsiyetlerine göre turizm mesleğine yönelik bağlılık düzeylerine göre, "Normatif Bağlllık" ve "Devamlılık Bağhllı̆̆ı" faktörlerinde anlamlı farklılık tespit edilmiştir. Anlamlı farklılık tespit edilen her iki faktöre ilişkin sıra ortalamaları incelendiğinde, erkeklerin algılarının, kadınların algılarına oranla daha olumlu olduğu görülmektedir. Başka bir ifade ile bu sonuç, erkeklerin isteseler dahi mevcut işlerinden ayrılamayacağı, mesleklerine bağlı olmayı ve/veya çalışmayı bir zorunluluk olarak gördükleri anlamını taşımaktadır. Bu sonuçlara göre verilen $\mathrm{H} 1$ araştırma hipotezi $\mathbf{k a b u l}$ edilmiştir.

Tablo.4 Öğrencilerin Mesleki Bağlılık Düzeylerinin Sınıflarına Göre Karşılaştırılması

\begin{tabular}{|c|c|c|c|c|c|c|c|c|c|}
\hline Faktörler & & 11. $S$ & & & 12. $S$ & & $U$ & $Z$ & $P$ \\
\hline & $N$ & $\begin{array}{l}\text { Sira } \\
\text { Ort. }\end{array}$ & Stra Top. & $N$ & $\begin{array}{l}\text { Sira } \\
\text { Ort. }\end{array}$ & Sira Top. & & & \\
\hline $\begin{array}{l}\text { Normatif } \\
\text { Bağlılık }\end{array}$ & 139 & 145,65 & 20246,00 & 138 & 132,30 & 18257,00 & 8666,000 & $\begin{array}{l}- \\
1,390\end{array}$ & 164 \\
\hline $\begin{array}{l}\text { Duygusal } \\
\text { Bağgllık }\end{array}$ & 142 & 145,75 & 20696,50 & 137 & 134,04 & 18363,50 & 8910,500 & $\begin{array}{l}- \\
1,220\end{array}$ & ,223 \\
\hline $\begin{array}{l}\text { Devamlulık } \\
\text { Bă̆glllı̆ğ }\end{array}$ & 143 & 144,63 & 20682,50 & 144 & 143,37 & 20645,50 & 10205,50 & - &, 896 \\
\hline
\end{tabular}


Turizm lisesi öğrencilerinin şuanda okudukları sınıf özelliklerine göre mesleki bağlılık algılarındaki anlamlı farklılıkları belirlemek için verilen $\mathrm{H} 2$ araştırma hipotezinin testi için Man Whitney-U testinden yararlanılmış ve analiz sonuçları Tablo.4'de gösterilmiştir. Tablo.4 incelendiğinde, araştırmaya katılan öğrencilerin sınıf özelliklerine göre hiçbir faktörde anlamlı farklılık gözlemlenememiştir. Turizm lisesi öğrencilerinin 11. sinıf veya 12. sinıfta okuyor olmalarının onların mesleki bağlılık algıları üzerinde anlamlı bir etkisinin olmayışı, iki sınıf arasında algılar üzerinde anlamlı farklılıkları ortaya çıkaracak kadar önemli bir zaman farkı olmadığı anlamına da gelebilir. Bu sonuçlara göre verilen $\mathrm{H} 2$ araştırma hipotezi reddedilmiştir.

Tablo.5 Öğrencilerin Staj Yaptıkları İşletmeye Göre Man Whitney-U testi Sonuçları

\begin{tabular}{|c|c|c|c|c|c|c|c|c|c|}
\hline Faktörler & & Ote & & & Acen & & $U$ & $Z$ & $P$ \\
\hline & $N$ & $\begin{array}{l}\text { Sira } \\
\text { Ort. }\end{array}$ & Stra Top. & $N$ & $\begin{array}{l}\text { Sira } \\
\text { Ort. }\end{array}$ & Stra Top. & & & \\
\hline $\begin{array}{l}\text { Normatif } \\
\text { Bă̆gllık }\end{array}$ & 202 & 146,93 & 29680,00 & 75 & 117,64 & 8823,00 & $\begin{array}{l}5973,00 \\
0\end{array}$ & $-2,709$ &, $007^{* *}$ \\
\hline $\begin{array}{l}\text { Duygusal } \\
\text { Bağlllık }\end{array}$ & 203 & 141,42 & 28707,50 & 76 & 136,22 & 10352,50 & $\begin{array}{l}7426,50 \\
0\end{array}$ &,- 482 & ,630 \\
\hline $\begin{array}{l}\text { Devamlılık } \\
\text { Bağglılığ }\end{array}$ & 209 & 144,37 & 30173,00 & 78 & 143,01 & 11155,00 & $\begin{array}{l}8074,00 \\
0\end{array}$ &,- 125 & ,901 \\
\hline
\end{tabular}

Turizm lisesi öğrencilerinin staj yaptıkları işletmeye göre mesleki bağlılık algılarındaki anlamlı farklılıkları belirlemek için verilen H3 araştırma hipotezinin testi için Man Whitney-U testinden yararlanılmış ve analiz sonuçları Tablo.5' de gösterilmiştir. Tablo.5 incelendiğinde, öğrencilerin en son staj yaptıkları işletmeler göz önüne alındığında, "Normatif Bağ lılık" faktöründe anlamlı farklılık gözlemlenmiş, her iki bağımsız gruba ait sıra ortalamaları incelendiğinde, en son konaklama/otel işletmesinde staj yapan öğrencilerin görüşlerinin, seyahat/acente işletmesinde staj yapan öğrencilerin görüşlerinden daha olumlu olduğu görülmüştür (Sıra Ort= 146,93). Ortaya çıkan bu sonuca göre, öğrencilere sağlanan imkânlar göz önüne alındığında, konaklama/otel işletmelerinde staj yapan öğrencilerin, seyahat/acente işletmelerinde staj yapan öğrencilere oranla mesleklerine daha fazla bağlı oldukları görülmektedir. Bu sonuçlara göre verilen $\mathrm{H} 3$ araştırma hipotezi $k a b u l$ edilmiştir.

\section{SONUÇ VE TARTIŞMA}

Bu çalışmanın amacı, İstanbul'da bir Turizm Meslek Lisesi'nde öğrenim gören ve en az bir staj dönemi turizm sektöründe çalışmış 11. ve 12. Sınıf öğrencilerinin demografik değişkenlerine göre mesleki bağlılık düzeylerinin belirlenmesidir. Bireylerin mesleki bağlılıklarını etkileyen birçok etkenin varlığı (zorunluluk, duygusallık, devamlılık vb.), ilgili literatürde sıklıkla tartışılmasının yanı sıra, bu bağlılığın bireylerin demografik özelliklerine duyarlı olup olmadığının bilinmesi de önemli olabilir. Araştırmada bu amaçla verilen hipotezler sınanmıştır. Verilen H1 araştırma hipotezinde, Turizm Meslek Lisesi öğrencilerinin cinsiyetlerine göre, turizm mesleğine yönelik bağlılık düzeylerinde anlamlı farklılık olup olmadığı, Man Whitney-U testi ile araştırılmıştır.

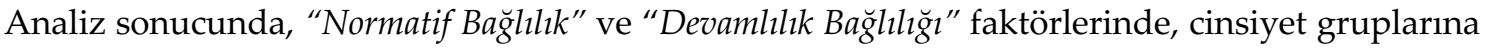
göre anlamlı farklılık tespit edilmiş ve erkek öğrencilerin algılarının, kız öğrencilerin algılarından 
daha olumlu olduğu görülmüştür. Ortaya çıkan bu bulgu, Güneş vd., çalışması ile benzerlik göstermektedir (Güneş vd., 2009).

Faktör ifadeleri incelendiğinde, erkek öğrencilerin genç yaştan itibaren mesleklerine ilişkin zorunluluk duygusu ile mesleklerine bağlı oldukları, çalışmayı sorumluluk ve/veya yükümlülük olarak gördükleri anlaşılmaktadır. Türk toplumlarında erkeğin, özellikle aile içerisindeki yeri düşünüldüğünde, kendilerine yüklenen para kazanma misyonu ile birlikte, genç yaştan itibaren çalışmayı bir zorunluluk olarak gördükleri söylenebilir. Başka bir ifadeyle bu durum, erkek öğrencilerin isteseler dahi mesleklerinden ayrılma eğiliminde olmadıkları, mutsuz olsalar dahi, bu durumun kendileri için olumsuz sonuçlar doğuracağını düşündükleri anlamını da taşımaktadır. İşletmeler açısından bakıldığında bu durumun, mesleğine duygusal olarak bağlı olmayan, işverene karşı borçlu hissettikleri için o mesleği yapmayı sürdüren personeller ortaya çıardığ 1 söylenebilir. Bu sonucun, en basit haliyle işletmenin müşteri memnuniyeti veya memnuniyetsizliğine yansıması kaçınılmaz olacaktır. Özellikle erkek öğrencilere ilişkin bu bağlllık türünü ortaya çıkartan faktörlerin ve/veya düşüncelerin ne olduğunun belirlenmesi, benzer şekilde kız öğrencilerin, turizm mesleğine ilişkin bu bağlılık düzeylerini düşüren etmenlerin araştırılması, turizmde hizmet kalitesinin yaratılması adına önemli ipuçları verebilir.

Araştırma kapsamında verilen ve Turizm Meslek Lisesi öğrencilerinin sınıf düzeylerine göre turizm mesleğine yönelik bağlılık düzeylerinde anlamlı farklılık olup olmadığının araştııldığı H2 araştırma hipotezinin testi için benzer şekilde Man Whitney-U testinden yararlanılmıştır. Ancak, analiz sonucunda öğrencilerin sınıf özelliklerine göre bağımsız gruplar arasından anlamlı farklılıklar belirlenememiştir. Başka bir ifadeyle, öğrencilerin sınıf düzeyi, turizm mesleğine ilişkin mesleki bağlılık üzerinde duyarlı bulunamamıştır. Çalışmaya katılan ve turizm sektöründe en az bir dönem staj yapma tecrübesine sahip öğrenciler, 11. ve 12. sinıfta öğrenim görmektedir. Görece aynı yaş aralığında olan ve görece aynı süre iş tecrübesine sahip olan öğrencilerin algıları, anlamlı düzeyde farklılaşmamaktadır. Bu açıdan ortaya çıkan bu sonuç beklenen bir durumdur.

Araştırma kapsamında, öğrencilerin en son çalıştıkları turizm işletmesine göre turizm mesleğine yönelik bağlılık düzeylerindeki anlamlı farklılıkları ortaya çıkarmak üzere verilen son araştırma hipotezinin testi için yapılan analiz sonucunda, sadece normatif bağlılık faktöründe anlamlı bir farklılık tespit edilmiş ve konaklama/otel işletmelerinde staj yapan öğrencilerin algılarının, seyahat/acente işletmelerinde staj yapan öğrencilerin algılarından daha olumlu olduğu görülmüştür. Bu durum konaklama/otel işletmelerinde staj yapmış öğrencilerin, seyahat/acente işletmelerinde staj yapmış öğrencilere oranla kendilerini normatif olarak turizm mesleğine daha bağlı hissetlerinin bir göstergesidir. Turizm sektörünün en önemli işletmelerinden birisi olarak konaklama/otel işletmelerinin, öğrencilere sunduğu farklı departmanlarda kariyer imkânı, öğrencilerin konaklama/otel işletmelerine yönelik, mesleki bağlılık algılarını etkiliyor olabilir. Öyle ki, staj ile birlikte konaklama/otel işletmelerinin herhangi bir departmanında çalışmaya başlayan öğrencilerin, seyahat işletmelerinde çalışmaya başlayan öğrencilere oranla, kendilerini daha fazla turizmin bir parçası olarak görmeye başladıkları yorumu da yapılabilir. Benzer şekilde, çalışan sayısının konaklama/otel işletmelerine oranla az olduğu seyahat/acente işletmelerinde kariyer yapmanın zor olduğu düşüncesi, öğrencilerin bu yönde algılarını etkiliyor olabilir. Bir diğer önemli husus, staj yaptıkları işletme farklılığı göz önüne alınmaksızın, Turizm Meslek Lisesi'nde okuyor olmanın öğrenciler üzerinde yarattığı, artık lise ve meslek değiştirmenin görece zor ve hatta imkânsız olacağı bilincinin de normatif bağlllık üzerinde etkili olabileceği unutulmamalıdır.

Bir ülkenin genel turizm hizmet kalitesi düşünüldügünde, çalışma hayatlarında çeşitli turizm işletmelerinin hemen her departman ve kademesinde görev alacak olan, başta Turizm Meslek Lisesi öğrencilerinin mesleki bağlllık düzeylerinin bilinmesi önemlidir. Bu noktada, özellikle 
Turizm Meslek Lisesi yönetiminin ve öğretmenlerinin, özellikle öğrencilerin cinsiyet ve staj yaptıkları işletmelere göre ortaya çıkan normatif ve devam bağlllığı yaratan faktörlerin tespit edilmesi, gerekirse bu faktörlerin bertaraf edilerek, öğrencilerin mesleklerine duygusal olarak bağlı olmalarını sağlayacak psikolojik destek ve/veya eğitimler verilmesi sağlanabilir. Ayrıca lise dönemlerinden itibaren meslekleriyle iç içe olan öğrencilerin, ilgili sektöre bağlllıklarının ilerleyen dönemlerde de ölçülmesi, sonuçların karşılaştırılması açısından önemli olabilir. Ülkemizde son zamanlarda turizm sektörüne kalifiye eleman kazandırma arayışı hız kazanmıştır ve turizm lisesi öğrencilerinden başlayarak mesleki bağlılık oluşturulması sektör için oldukça önemli bir durumdur. Aynı zamanda yüksekokul ve fakülte bünyesinde doluluk sorunu yaşamaya başlayan turizm bölümleri, turizm lisesi öğrencilerinde oluşacak mesleki bağlllık ile farklı bölümler yerine turizmde eğitim almaya devam edecek olmaları bu bölümlerinde doluluk oranlarını arttıracak ve kalifiye eleman sayısında da artışı beraberinde getirecektir.

\section{KAYNAKÇA}

Aslan, Ş. (2008), Örgütsel Vatandaşlık Davranışı İle Örgütsel Bağlılık ve Mesleğe Bağlllık Arasındaki İlişkilerin Araştırılması, Celal Bayar Üniversitesi Yönetim ve Ekonomi Dergisi, 15 (2). 163 178

Başol, G. ve Yalçın, B. (2009). Eğitim Örgütlerinde Meyer ve Allen Üç Boyutlu Örgütsel Bağlllık Ölçeğinin Geçerlik ve Güvenirlik Çalışması. The 5th International Balkan Educational and Science Congress, 2, 497-507, Trakya University, Edirne, Turkey.

Baysal, A. C. ve Paksoy, M. (1999). Mesleğe ve Örgüte Bağlllığın Çok Yönlü İncelenmesinde Meyer-Allen Modeli. İstanbul Üniversitesi İşletme Fakültesi Dergisi, 28(1), 7-15.

Blau, G. (2003). Testing for A Four-Dimensional Structure of Occupational Commitment. Journal of Occupational and Organizational Psychology, 76(4), 469-488.

Büyüköztürk, Ş. (2011). Sosyal Bilimler İçin Veri Analizi El Kitabı. Ankara: Pegem.

Carson, K. D., Carson, P. P. and Bedeian, A. G., (1995). Development and construct validation of career entrenchment measure. Journal of Occupationaland Organizational Psychology, 68, 301320.

Carson, K. D., Carson, P. P., Phillips, J. S. and Roe, C. W. (1996). A Career Entrenchment Model: Theoretical Development and Empirical Outcomes. Journal of Career Development, 22(4), 273-286.

Carson, K. D., and Carson, P. P., (1997). Career entrachment: A quite march toward occupational death? Academy of Management Executive, 11(1), 62-75.

Chakrapani, C. (2004). Statistics in Market Research. London: Arnold Publisher.

Cortina, J. M. (1993). What Is Coefficient Alpha? An Examination of Theory and Applications. Journal of Applied Psychology, Vol. 78, No. 1, 98-104.

Cronbach, L. J. (1990). Essentials of Psychological Testing. New York: Harper \& Row.

Çekmecelioğlu, H. G. (2006). Örgüt İklimi, Duygusal Bağlılık ve Yaratıcılık Arasındaki İlişkilerin Değerlendirilmesi: Bir Araştırma. Atatürk Üniversitesi İktisadi ve İdari Bilimler Dergisi, 20 (2). 295310.

Çelik, M. ve Yıldız, B. (2018), Hemşirelerde Mesleki Bağlılık, Özdeşleşme ve İşten Ayrılma Niyeti İlişkisi: Kamu Sektörü Ve Özel Sektör Karşılaştırması. Kastamonu Üniversitesi İktisadi ve İdari Bilimler Fakültesi Dergisi, 20(2), 47-75. 
Çetin, A., Erenler, E., ve Şentürk, M. (2016). Mesleki Bağlllık ve Mesleki Öz-yeterlik Algısının Bilgi Paylaşma Davranışına Etkisi. Çankırı Karatekin Üniversitesi İIBF Dergisi, 6(2), 289-316.

Çolakoğlu, Ü., Ayyıldız, T. ve Cengiz, S. (2009). Çalışanların Demografik Özelliklerine Göre Örgütsel Bağlılık Boyutlarında Algılama Farklılıkları: Kuşadası'ndaki Beş Yıldızlı Konaklama İşletmeleri Örneği. Anatolia: Turizm Araştırmaları Dergisi, 20(1). 77-89.

Güneş, İ., Bayraktaroğlu, S. ve Kutanis, R. Ö. (2009). Çalışanların Örgütsel Bağlllık ve Tükenmişlik Düzeyleri Arasındaki İlişki: Bir Devlet Üniversitesi Örneği. Süleyman Demirel Üniversitesi İktisadi Ve İdari Bilimler Fakültesi Dergisi, 14(3). 481-497.

Hair, J. F., Black, W. C., Babin, B. J., Anderson, R. E. and Tatham, R. L. (2006). Multivariate Data Analysis. New Jersey: Prentice Hall.

Lin, S., Professor David Lamond, P., Yuan, L., Yu, Y., Li, J. and Ning, L. (2014)," Occupational Commitment, Industrial Relations and Turnover Intention: Empirical Evidence from China", Chinese Management Studies, 8(1), 66-84

Meyer, J. P., Allen, N. J. and Smith, C. A. (1993). Commitment to Organizations and Occupations: Extension and Test of a Three-Component Conceptualization. Journal of Applied Psychology, Vol: 78, No: 4, 538-551.

Morrow, P. C. (1983). Conceptredundancy in organizational research: The case of work commitment. The Academy of Management Review, 8(3), 486-500.

Nakip, M. (2003). Pazarlama Araştırmaları: Teknikler ve Uygulamalar. Ankara: Seçkin Kitapevi.

Özmen, Ö. T., Özer, P. S. ve Saatçioğlu, Ö. Y. (2005). Akademisyenlerde Örgütsel ve Mesleki Bağlılığın İncelenmesine İlişkin Bir Örnek Araştırma. Dokuz Eylül Üniversitesi İşletme Fakültesi Dergisi, 6 (2). 1-14.

Tak, B. ve Çiftçioğlu, B. A. (2008). Mesleki Bağlllık İle Çalışanların Örgütte Kalma Niyeti Arasındaki İlişkiyi İncelemeye Yönelik Görgül Bir Çalışma. Ankara Üniversitesi Siyasal Bilgiler Fakültesi Dergisi, 63(4), 155-178.

Tak, B. ve Çiftçioğlu, B. A. (2009). Üç Boyutlu Mesleki Bağlılık Ölçeğinin Türkçe'de Güvenilirlik ve Geçerliliğinin İncelenmesine Yönelik Bir Alan Araştırması. İşletme Fakültesi Dergisi, 10(1), 3554 .

Uysal, H. T. (2013). Stajyer Çalışanların Mesleki Bağlllık Gelişimine Örgüt İkliminin Etkisi/Effect of Organizational Climate to Professional Commitment Development of Intern Workers. Business and Economics Research Journal, 4(3), 93-110

Van der Heijden, B. I., van Dam, K. and Hasselhorn, H. M. (2009)," Intention to Leave Nursing: The Importance of Interpersonal Work Context, Work-home Interference, and Job Satisfaction Beyond the Effect of Occupational Commitment", Career Development International, 14(7), 616635.

Şimşek, M. Ş. ve Aslan, Ş. (2012). Meslekî ve Örgütsel Bağlılığın, Örgütsel Davranışa İlişkin Sonuçlarla İlişkileri. Sosyal Ekonomik Araştırmalar Dergisi, 12(23), 414-454.

Yazıcıoğlu, Y. ve Erdoğan, S. (2004). SPSS Uygulamalı Bilimsel Araştırma Yöntemleri. Ankara: Detay Yayıncilık. 